\title{
Colonial Statistics
}

Government Statisticians and Directors of Statistics from each of the chief Colonial regions met in London on I 5 March 1950 for a fortnight's statistical conference-the first of its kind. On 22 March a meeting of the Royal Statistical Society was devoted to the discussion of Colonial Statistics when Mr. W. F. Searle, Chief Statistician at the Colonial Office, read a paper on the present scope of Colonial Statistics and the resources available for their development. He referred to censuses of population, which are now taken in nearly all British colonial territories, although varying standards of enumeration have to be adopted in different areas, and the extent to which inquiries into ages, numbers of children, occupations, \&c. are practicable, is a major problem. Statistics on agricultural production are available only where products enter wholesale trade. There are certain records of purchases for export and of food commodities, such as quantities marketed for urban consumption; examples of efforts to make this kind of information more complete are the current surveys of cocoafarming in Nigeria and the Gold Coast. Estimates of the trend of food supplies over a whole territory or a special area cannot be made owing to lack of information on subsistence crops; estimates of livestock population are in existence, but, in Africa particularly, local opposition to counting, and misleading figures derived from taxation figures, are a great handicap. The development of statistical work in the Colonies will be speeded up as more trained local staff becomes available. The statistics department of the Colonial Office does all it can to ensure that useful techniques developed in one country are made known in all territories, and is also working on the problem of adapting existing methods to special conditions applying, for example, in Africa.

In this connexion, some interest attaches to a recent publication entitled Population Censuses and other Official Demographic Statistics, ${ }^{1}$ sponsored by the United States Bureau of the Census and the Library of Congress; it consists of an annotated bibliography of all censuses taken in British African Territories, ranging from the I 85 I census of Mauritius to the 1948 census of Kenya. It includes numerous other statistical and demographic reports, such as medical reports, reports on vital statistics, reports on labour problems and mining conditions, reports to the United Nations. Many of the items are accompanied by a more or less detailed summary of the material dealt with, and ethnographic studies such as Amaury Talbot's The Peoples of Southern Nigeria and Meek's Northern Tribes of Nigeria receive lengthy notices. The book includes a list of Colonial Office papers and annual Colonial Reports. Though it purports to deal only with British Africa, material relating to the Union of South Africa and South-West Africa, and reports on the oversea territories of Germany prior to 1914 are included.

The Executive Council of the International African Institute, at its meeting in April I950, discussed the question of demographic studies of African peoples, and the need for an analysis of statistical information on primitive societies, in a form which would be more useful to students of sociology. It was proposed that the Institute should prepare a memorandum setting forth the principles of demography and their relation to existing problems.

\section{Excavations at Inyanga Ruins}

AN archaeological expedition is now at work on the excavation of the Van Niekerk ruins at Inyanga in the north-east of Southern Rhodesia. The excavations are being undertaken by a committee under the direction of Mr. Roger Summers of the National Museum, assisted by Mr. K. R. S. Robinson who has already done valuable work at the Khami ruins near Bulawayo. Diggers have been recruited mainly from amateur archaeologists, members of

I Population Censuses and other Official Demographic Statistics of British Africa; prepared by Henry J. Dubester, Chief, Census Library Project, Library of Congress. Washington, 1950, price 20 cents. 